\title{
JENIS - JENIS PATEN DAN JANGKA WAKTU PERLINDUNGAN PATEN
}

\author{
Arga Ade Audiya \\ 175100064P \\ Fakultas Komputer, 448757149 \\ Argaadeaudiya.student@umitra.ac.id
}

\begin{abstract}
Paten merupakan hak khusus yang diberikan Negara kepada Penemu atas hasi penemuannya di bidang teknologi, untuk lama waktu tertentu melaksanakan sendiri penemuannya tersebut atau memberikan persetujuannya kepada orang lain untuk melaksanakannya, jenis - jenis paten yaitu paten dan paten sederhana. Paten adalah hak eksklusif yang diberikan oleh negara kepada inventor atas hasil invensinya di bidang teknologi yang untuk selama waktu tertentu melaksanakan sendiri atau memberikan persetujuan kepada pihak lain untuk melaksanakannya sedangkan Paten Sederhana adalah setiap invensi berupa produk atau alat yang baru dan mempunyai nilai kegunaan praktis disebabkan oleh bentuk, konfigurasi, konstruksi, atau komponennya dapat memperoleh perlindungan hukum dalam bentuk paten sederhana

Jangka Waktu Perlindungan Paten Sebagaimana diketahui di dalam pasal 8 ayat 1 undang - undang nomor 14 tahun 2001 tentang Paten menyebutkan bahwa paten diberikan untuk jangka waktu 20 (Dua puluh tahun) terhitung sejak tanggal penerimaandan jangka waktu itu tidak dapat diperpanjang, sedangkan untuk paten sederhana diberikan untuk jangka waktu 10 (Sepuluh tahun) terhitung sejak tanggal penerimaandan jangka waktu itu tidak dapat diperpanjang, Jika masa perlindungan hak paten telah berakhir, maka suatu evensi akan menjadi public domain sehingga pihak lain dapat memproduksi dan menjualnya secara bebas. Aturan mengenai masa berlaku paten dimaksudkan agar tidak ada pihak yang secara terus menerus dapat mengontrol seluruh industri sehingga dikhawatirkan dapat merugikan masyarakat dan sistem perdagangan.
\end{abstract}

Kata Kunci : Jenis-Jenis paten, jangka waktu 


\section{A. INTRODUCTION}

Apa Itu Paten ??

Paten adalah hak khusus yang diberikan Negara kepada Penemu atas hasi penemuannya di bidang teknologi, untuk lama waktu tertentu melaksanakan sendiri penemuannya tersebut atau memberikan persetujuannya kepada orang lain untuk melaksanakannya (Pasal 1 ayat 1 UU tentang Paten).

Dan, berdasarkan Pasal 1 angka 2 Undang-undnag Nomor 14 Tahun 2001 menyatakan bahwa, "invensi adalah ide inventor yang dituangkan kedalam suatu kegiatan pemecahan masalah yang spesifik di bidang teknologi dapat berupa produk atau proses atau penyempurnaan dan pengembangan produk atau proses."

Berdasarkan makna dari invensi tersebut dapat dilihat bahwa ciri khas yang dapat dipatenkan adalah kandungan yang sistematis yang dapat dikomunikasikan diterapkan untuk menyelesaikan masalah atau kebutuhan manusia yang timbul dalam industri, pertanian, atau perdagangan.

\section{Jenis - Jenis Paten}

Dalam Undang-undang Nomor 14 Tahun 2001, paten dapat dibedakan dalam 2 (dua) jenis, yaitu :

1. Paten adalah hak eksklusif yang diberikan oleh negara kepada inventor atas hasil invensinya di bidang teknologi yang untuk selama waktu tertentu melaksanakan sendiri atau memberikan persetujuan kepada pihak lain untuk melaksanakannya (Pasal 1 angka 1 Undang-undang Nomor 14 Tahun 2001); dan

2. Paten Sederhana adalah setiap invensi berupa produk atau alat yang baru dan mempunyai nilai kegunaan praktis disebabkan oleh bentuk, konfigurasi, konstruksi, atau komponennya dapat memperoleh perlindungan hukum dalam bentuk paten sederhana (Pasal 6 Undangundang Nomor 14 Tahun 2001).

Antara kedua jenis paten tersebut memiliki beberapa perbedaan diantaranya :

Jika, Paten :

1. Teknologi rumit;

2. Invensi produk dan proses;

3. Persyaratan materiil yang harus baru, ada langkah inventif dan diterapkan dalam industri serta tidak termasuk invensi dalam Pasal 7; 
4. Pemeriksaan substantif dikatakan lolos, apabila invensi memenuhi Pasal 2, 3, 5, 7 UUP;

5. Untuk melakukan pemeriksaan substantif harus mengajukan permohonan pemeriksaan substantif;

6. Dapat dimintakan lisensi wajib;

7. Jangka waktu perlindungan 20 tahun sejak tanggal penerimaan.

Sedangkan Paten Sederhana :

1.Teknologi lebih sederhana ditekankan pada fungsi praktis;

2. Produk/kasat mata (produk); 3.Syarat materiil paten sederhana adalah baru dan dapat diterapkan dalam industri;

4.Pemeriksaan substantif hanya meliputi, nilai kebaharuan dan dapat diterapkan dalam industri; 5.Untuk melakukan pemeriksaan substantif dapat dilakukan dengan bersamaan dengan pengajuan permohonan atau paling lama 6 bulan sejak tanggal penerimaan;dan

6. Tidak dapat dimintakan lisensi wajib; dan 7. Jangka waktu perlindungan 10 tahun sejak tanggal penerimaan.

\section{Jangka Waktu Perlindungan Paten}

Sebagaimana diketahui di dalam pasal 8 ayat 1 undang undang nomor 14 tahun 2001 tentang Paten menyebutkan bahwa paten diberikan untuk jangka waktu 20 (Dua puluh tahun) terhitung sejak tanggal penerimaandan jangka waktu itu tidak dapat diperpanjang, sedangkan untuk paten sederhana diberikan untuk jangka waktu 10 (Sepuluh tahun) terhitung sejak tanggal penerimaandan jangka waktu itutidak dapat diperpanjang,

Jika masa perlindungan hak paten telah berakhir, maka suatu evensi akan menjadi public domain sehingga pihak lain dapat memproduksi dan menjualnya secara bebas. Aturan mengenai masa berlaku paten dimaksudkan agar tidak ada pihak yang secara terus menerus dapat mengontrol seluruh industri sehingga dikhawatirkan dapat merugikan masyarakat dan sistem perdagangan.

3. Definisi Inventor dan Pemegang Paten

Inventor merupakan penemu atau salah satu subjek paten, dalam hal ini yang dapat dijadikan inventor hanya orang, baik perorangan ataupun lebih dari stau orang yaitu bersama-sama. Dalam undang-undang definisi 
inventor adalah seorang yang secara sendiri atau beberapa orang yang secara bersamasama melaksanakan ide yang dituangkan ke dalam kegiatan yang menghasilkan invensi. Di lain pihak juga dikenal adanya pemegang hak yaitu pemegang paten adalah inventor sebagai pemilik paten atau pihak yang menerima hak lebih lanjut tersebut, yang terdaftar dalam daftar umum paten.

Dalam kenyataannya inventor tidak memiliki kemampuan untuk melaksanakan paten maupun menemukan suatu invensi mengingat di butuhkannya biaya yang tidak sedikit dalam melaksanakan paten atau penelitian untuk menghasilkan suatu invensi, maka untuk mengantisipasi hal ini Undang-undang memberikan jalan keluar dalam bentuk pengalihan paten.

4. Subjek Paten dan Objek Paten (Paten Proses dan Paten Produk)

Membahas ketentuan subjek paten berarti mengkaji tentang inventor yang merupakan penemu atau salah satu subjek paten, dalam hal ini yang dapat dijadikan inventor hanya orang, baik perorangan ataupun lebih dari stau orang yaitu bersama-sama. Dalam undang-undang definisi inventor adalah seorang yang secara sendiri atau beberapa orang yang secara bersamasama melaksanakan ide yang dituangkan ke dalam kegiatan yang menghasilkan invensi. Di lain pihak juga dikenal adanya pemegang hak yaitu pemegang paten adalah inventor sebagai pemilik paten atau pihak yang menerima hak lebih lanjut tersebut, yang terdaftar dalam daftar umum paten.

Sedangkan yang disebut dengan objek paten terdiri dari dua jenis, yaitu paten proses dan paten produk. Paten proses adalah klaim terhadap proses dari invensi yang dibuat oleh inventor. Paten proses mencakup proses atau penggunaan. Contohnya, proses membuat tinta, dan sebagainya. Sedangkan, paten produksi adalah klaim terhadap invensi yang berupa produk yang dibuat oleh inventor. Paten produk mencakup alat, mesin, komposisi, formulasi produk bagi proses, sistem, dan lainlain. Contohnya, alat tulis penghapus, komposisi obat, dan sebagainya.

$\begin{array}{lcr}\text { 5. Hak } & \text { Dan Kewajiban } \\ \text { Pemegang } & \text { Hak }\end{array}$

Pemegang hak Paten maupun inventor tetap memiliki hak untuk mengeksploitasi patennya, selain memiliki hak moral yang tetap melekat pada inventor. Hak pemegang paten 
antara

lain

1. Hak moral, yaitu pengalihan

hak tidak menghapus hak

inventor untuk tetap

dicantumkan nama dan indentitasnya dalam paten yang bersangkutan (Pasal 68);

2. Hak ekonomi, yaitu inventor tetap memperoleh hak ekonomi (manfaat ekonomi) sebagai imbalan. Imbalan tersebut dikenal dengan royalti (Pasal 12 ayat 3 dan 4); 3. Pemegang hak memiliki hak eksklusif untuk melaksanakan paten yang dimiliki dan melarang pihak lain tanpa persetujuan, misalnya membuat, menggunakan, dan menjual (Pasal 16 ayat 1); 4. Hak pengalihan dan memberikan haknya (Pasal 16 ayat 1). Di lain pihak, pemegang hak tetap memiliki kewajibannya yaitu :

1. Berdasarkan Pasal 17 menyatakan bahwa, "dengan tidak mengurangi ketentuan Pasal 16 ayat 1 , pemegang paten wajib melaksanakan produk atau menggunakan proses yang diberikan paten di Indonesia."

2. Berdasarkan Pasal 18 menyatakan bahwa, "pemegang paten atau penerima lisensi diwajibkan untuk membayar biaya tahunan untuk mengelola kelangsungan berlakunya paten dan pencatatan lisensi."

\section{B. CONCLUSION}

\section{Kesimpulan}

Paten adalah hak khusus yang diberikan Negara kepada Penemu atas hasi penemuannya di bidang teknologi, untuk lama waktu tertentu melaksanakan sendiri penemuannya tersebut atau memberikan persetujuannya kepada orang lain untuk melaksanakannya (Pasal 1 ayat 1 UU tentang Paten).

Dalam Undang-undang Nomor 14 Tahun 2001, paten dapat dibedakan dalam 2 (dua) jenis, yaitu Paten dan Paten sederhana

Sebagaimana diketahui di dalam pasal 8 ayat 1 undang undang nomor 14 tahun 2001 tentang Paten menyebutkan bahwa paten diberikan untuk jangka waktu 20 (Dua puluh tahun) terhitung sejak tanggal penerimaandan jangka waktu itu tidak dapat diperpanjang, sedangkan untuk paten sederhana diberikan untuk jangka waktu 10 (Sepuluh tahun) terhitung sejak tanggal penerimaandan jangka waktu itutidak dapat diperpanjang,

Jika masa perlindungan hak paten telah berakhir, maka suatu evensi akan menjadi public domain sehingga pihak lain dapat memproduksi dan menjualnya secara bebas. Aturan mengenai masa berlaku 
paten dimaksudkan agar tidak ada pihak yang secara terus menerus dapat mengontrol seluruh industri sehingga dikhawatirkan dapat merugikan masyarakat dan sistem perdagangan.

\section{ACKNOWLEDGEMENT} University Of Indonesia University Of Mitra Indonesia Telkom University University Of Mellbourne Saitama University

\section{REFERENCE(Based ISO 690 )}

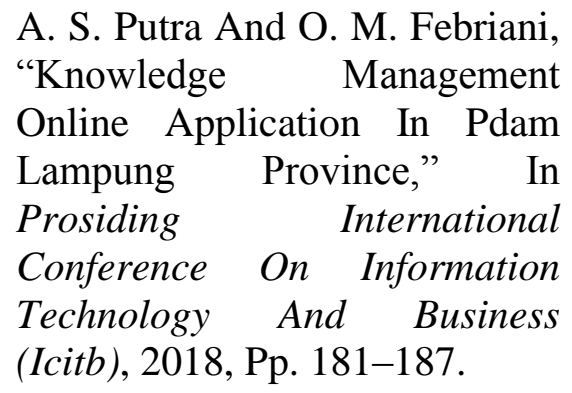

[2] A. S. Putra, O. M. Febriani, And B. Bachry, "Implementasi Genetic Fuzzy System Untuk Mengidentifikasi Hasil Curian Kendaraan Bermotor Di Polda Lampung," J. Sist. Inf. Dan Manaj. Basis Data, Vol. 1, No. 1, Pp. 21-30, 2018.

[3] O. M. Febriani And A. S. Putra, "Sistem Informasi Monitoring Inventori Barang Pada Balai Riset Standardisasi Industri Bandar Lampung," J. Inform., Vol. 13, No. 1, Pp. 90-98, 2014.

[4] Putra, Arie Setya. "2018 Artikel Struktur Data, Audit Dan Jaringan Komputer." (2018).
[5] Putra, A. S. (2018, July 17). Paperplain Fundamental Create Application With Borland Delphi 7.0 University Of Mitra Indonesia. Retrieved From Osf.Io/Pbrn9.

\section{E. REFERENCE(Based APA )}

Putra, A. S., Aryanti, D. R., \& Hartati, I. (2018, November). Metode SAW (Simple Additive Weighting) sebagai Sistem Pendukung Keputusan Guru Berprestasi (Studi Kasus: SMK Global Surya). In Prosiding Seminar Nasional Darmajaya (Vol. 1, No. 1, pp. 85-97).

Sari, D. P., Febriani, O. M., \& Putra, A. S. (2018, November). Perancangan Sistem Informasi SDM Berprestasi pada SD Global Surya. In Prosiding Seminar Nasional Darmajaya (Vol. 1, No. 1, pp. 289-294).

Putra, A. S. (2018). Paperplain: Execution Fundamental Create Application With Borland Delphi 7.0 University Of Mitra Indonesia.

Putra, A. S., Sukri, H., \& Zuhri, K. Sistem Monitoring Realtime Jaringan Irigasi Desa (JIDES) Dengan Konsep Jaringan Sensor Nirkabel. IJEIS (Indonesian Journal of Electronics and Instrumentation Systems), 8(2), 221232. 
Darmawan, A., Yuliawati, D., Marcella, O., \& Firmandala, R. (2016). Sistem Absensi dan Pelaporan Berbasis Fingerprint dan SMS Gateway. EXPLORE, 7(1).

Febriani, O. M., Wahyuni, T., \& Yusuf, S. (2017). DESIGN OF WEBSITE-BASED INFORMATION SYSTEM FOR EDOCUMENT ADMINISTRASI IN THE COMMUNITY SERVICE UNIT (A Case Study at Rajabasa District). INTERNATIONAL JOURNAL OF COMPUTERS \& TECHNOLOGY, 16(7), 7010-7020.

Febriani, O. M., \& Wahyuni, T. (2017, October). PERANCANGAN SISTEM E-DOCUMENT ADMINISTRASI LOGBOOK PENELITIAN PADA UNIT LAYANAN DI BANDAR LAMPUNG. In Prosiding Seminar Nasional Darmajaya (Vol. 1, No. 1, pp. 187-194).

Febriani, O. M., \& Permadi, A. B. (2017). Implementasi Sistem Aplikasi Data Bimbingan dan Pelanggaran Siswa pada Sekolah Menengah Atas di Lampung Tengah dengan Metode Analisis dan Desain Sistem Terdistribusi (SSAD). EXPERT, 7(1).

Febriani, O. M., \& Ambarwati, L. (2015). PERANCANGAN APLIKASI PENGOLAHAN DATA PENJUALAN UKM KELANTING KHAS TELO DESA SIDOHARJO KECAMATAN JATI AGUNG KABUPATEN LAMPUNG SELATAN. Jurnal Teknologi
Informasi dan Bisnis Pengabdian Masyarakat Darmajaya, 1(1), 77-95.

Febriani, O. M. (2015). Rancang Bangun Aplikasi Ecommercemenggunakan Freewebstore pada UKM Kelanting di Desa Sidoharjo Lampung Selatan. Prosiding Sembistek 2014, 1(02), 446-458. 